\title{
INVESTIGATION OF CULLING PRACTICES ON A DAIRY FARM
}

\author{
Violetta Tóth $^{1}$, Virág Nagypál ${ }^{2}$, Ágnes Süli $^{1}$, Edit Mikó $^{1}$ \\ ${ }^{1}$ University of Szeged Faculty of Agriculture: Institute of Animal Sciences and Wildlife \\ Management, Address: 6800 -Hódmezővásárhely, Andrássy street 15., Hungary \\ ${ }^{2}$ University of Szeged Faculty of Agriculture: Institute of Economics and Rural \\ Development, Address: 6800 -Hódmezővásárhely, Andrássy street 15., Hungary \\ toth.violetta@mgk.u-szeged.hu
}

\begin{abstract}
Main aim of cattle breeding is to keep cattles with high productivity in production as long as possible. Thus length of productive lifetime can be increased. Culling is a complex decision. During that age, phases of lactation cycle, milk production, reproduction attributes and health stage all have to be taken into account. Optimal timing is important at culling as too early or too late culling results in economic loss. Culling decision is influenced by economic factors as well such as quantity and price of milk, price of culled cow, purchase price and raising cost of heifer. Many heifer have to be settled into production so all heifer which is suitable for reproduction has to be kept for breeding. As a result of this, all heifer that is healthy in context of reproduction biology has to be taken into breeding. Investigations of this study were made on a Hungarian dairy cattle farm. There is untied system on the farm. Cattles are grouped based on production level and stage of lactation. Daily milking number is three. Culling reasons were analysed in the first three lactations. Based on investigated data, 1175 cow were culled during five years which means 235 cows annually. There were differences between culling reasons. Udder health problems were the main reasons of culling. These presented $30 \%$ of the total cullings with 348 individuals. Several individuals were culled without fertilisation in the given lactation. The reason of this could be that the cow did not get pregnant again or other diseases and injuries occurred during lactation period. Most diseases occurred in the first 25 days of second lactation.
\end{abstract}

Keywords: dairy cattle, culling, replacement heifer, Holstein-Friesian

\section{INTRODUCTION}

Culling is a complex decision. During that age, phases of lactation cycle, milk production, reproduction attributes and health stage all have to be taken into account (BEAUDEAU, 1995). Reproduction disorders, mastitis, low milk yield and lameness are the principla causes of culling (BASCOM - YOUNG, 1998; CHIUMIA ET AL. 2013). Kerslake et al. (2018), calculated that reproduction disorders, mastitis and different diseases and mechanic injuries mean 10 dollar extra costs cow/year. According to them it would be important for the dairy farms to pay more attention on veterinarian treatments, genetics, production control and economic factors. Beaudeau et al. (1995), found that animal health problems has been identified as reason of half of the cullings. Nowadays, prevention has become more important than treating diseases (DERKS, 2014). It is typical for Hungary that cows are culled after 2,2-2,3 lactations on average. Therefore, all reproductive, biologically health heifers should be bred (HOLLÓ - SZABÓ, 2011). 


\section{MATERIAL AND METHOD}

The research was carried out in a dairy farm in Hungary. Holstein Friesian is the type of the herd. There are 475 cows. There is untied keeping system on the farm and the litter is straw. Cows are grouped according to production level and lactation phase. On the dairy farm the cows are milked three times a day. Milking parlour is parallel type.

\section{Description of investigation}

During the research the development of the culling reasons in the given herd were examined. More detailed research were made on culling due to mastitis. The somatic cell count of cows suffering from mastitis has been shown. Proportion of somatic cell number of cows in the first three lactation was analysed too. Further questions were answered as well like how many times cows get ill and in which phase of lactation disease first occure most frequently. Mastitis was detected by Californian Mastitis Test in all cases. Cows suffering from mastitis are isolated and separately milking them. Data about their productivity, medical treatment was recorded and stored in farm monitoring system. Data were gained from RISKA farm monitoring system. SPSS for Windows 18.0 program was used for the analysis. Data was processed and summarised in diagrams.

The applied statistical methods are shown in Table 1.

Table 1. Statistical methods applied for investigation

\begin{tabular}{|l|l|l|}
\hline \multicolumn{2}{|l|}{ Applied statistical methods } & Investigated area \\
\hline Chi $^{2}$ probe & Testing & \%-based distribution of culling \\
\cline { 1 - 1 } Cross-Tabulation Analysis & coherence & reasons in each lactations \\
& between & Serial number of fertilisations \\
& variables & depending on lactations \\
\hline
\end{tabular}




\section{RESULTS}

Data on the basics of the examination was collected between 2013 and 2017. The Figure 1. presents the distribution of culling reasons during the investigated period which was 5 years.

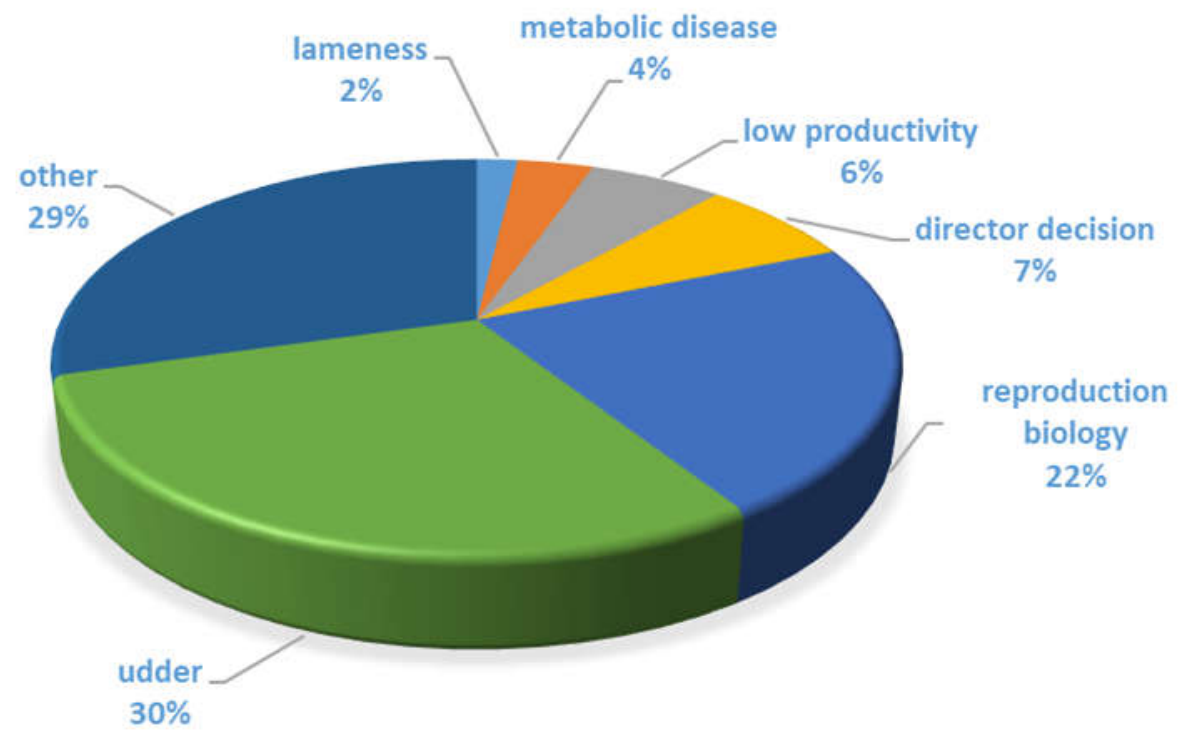

Figure 1. General investigation of culling reasons in the herd

All in all 1175 individulas are considered. There are significant differences between culling reasons. Mastitis takes the first place giving 30\% of total. The second highest portion of culling were other reasons such as lung inflammation, cardiac arrest, weakness, heat stress, mechanic injuries. $22 \%$ of cullings was caused by reproduction biology disorders. Low productivity, lameness, and metabolic diseases caused $12 \%$ of culling.

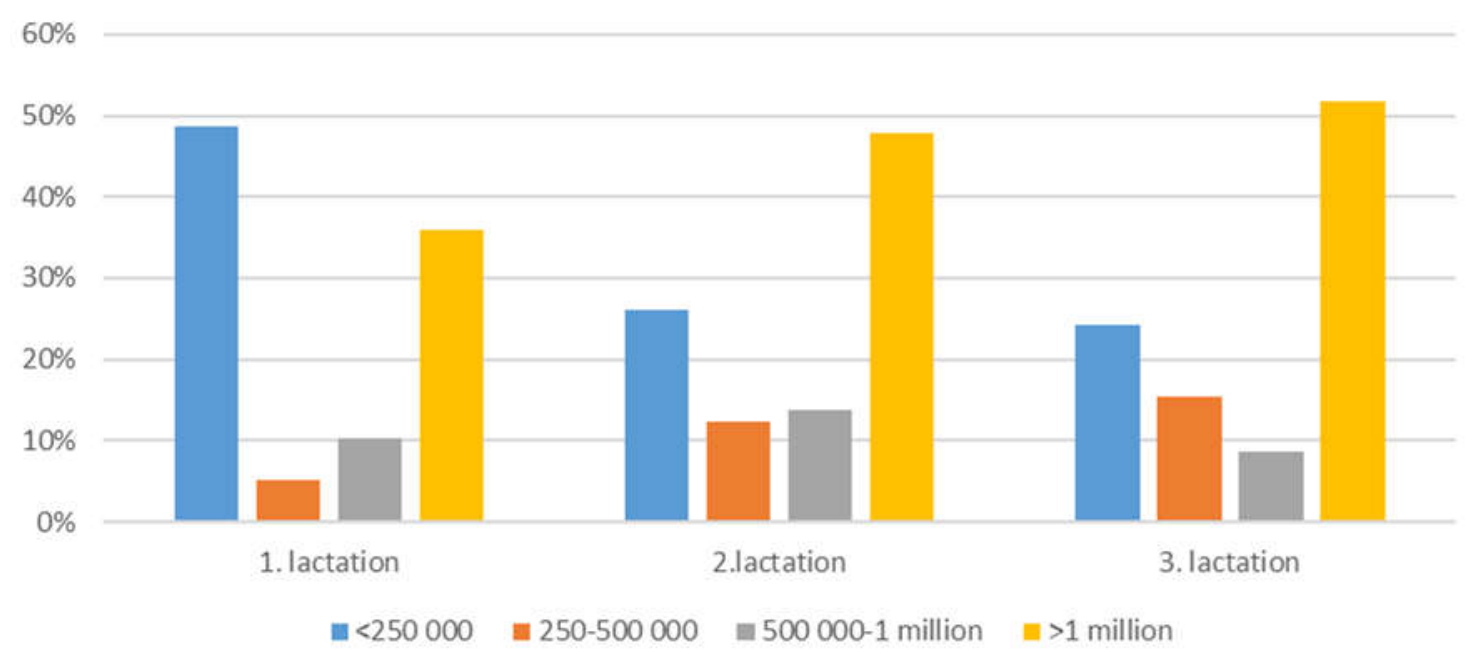

Figure 2. Distribution of somatic cell count in the first three lactation

Distribution of somatic cell count in the first three lactation is presented in Figure 2. The highest ratio of somatic cell count (SCC) was bellow $250000 \mathrm{cell} / \mathrm{ml}$ in the first lactation. Values between $250-500000 \mathrm{cell} / \mathrm{ml}$ just reached $5 \%$. 10\% was the proportion of 500 000-1 million cell $/ \mathrm{ml}$. The second highest ratio of SCC was above 1 million cell $/ \mathrm{ml}$ meaning approximately $36 \%$. As sum of these, lower than $250000 \mathrm{SCC}$ was typical. The second highest ratio was above 1 million SCC. In the second lactation approximately 50\% 
reached above 1 million SCC. Cell count bellow 250000 meant 26\%. SCC between 250 000 and 500000 and 500 000-1 million exceeded 10\%. Milk SCC of cows after culling in the third lactation exceeded 1 million cell count by almost 52\%. SCC bellow 250000 meaning 24\% had SCC between 250000 and 500000 was observable in $15.5 \%$. Proportion of the $500000-1$ million cell $/ \mathrm{ml}$ value did not exceed $10 \%$. As a conclusion, milk of cows after culling had more than 1 million SCC considering the highest proportions excluding the first lactation. Result of statistical probe presented significant difference in the distribution of observed indicators $\left(\mathrm{Chi}^{2}=20.903, \mathrm{df}=6, \mathrm{p}=0.002\right)$.

Table 2. Day of the first disease is signed by calving number in $\%$ in the given lactation

\begin{tabular}{|c|c|c|c|c|c|c|c|}
\hline \multirow[b]{2}{*}{ Calving number } & \multicolumn{6}{|c|}{ Day of the first disease occurrence in lactation } & \multirow[b]{2}{*}{ Total } \\
\hline & $<=25$ & $26-50$ & $51-100$ & $\begin{array}{c}101- \\
150\end{array}$ & $\begin{array}{c}151- \\
200\end{array}$ & $201+$ & \\
\hline 1 & 13.4 & 0.4 & 3.2 & 2.5 & 2.1 & 4.2 & 25.7 \\
\hline 2 & 16.5 & 2.5 & 7.0 & 3.5 & 1.8 & 3.5 & 34.9 \\
\hline 3 & 11.6 & 2.5 & 2.8 & 1.4 & 2.1 & 2.8 & 23.2 \\
\hline 4 & 3.9 & 0.7 & 2.5 & 0.4 & 0.4 & 1.8 & 9.5 \\
\hline$>4$ & 5.6 & & & 0.4 & 0.4 & 0.4 & 6.7 \\
\hline Total & 51,1 & 6.0 & 15.5 & 8.1 & 6.7 & 12.7 & 100.0 \\
\hline
\end{tabular}

Table 3. shows that the most diseases occurred after the second lactation representing $34.9 \%$. After the first and second calving diseases occurred diseases occurred with similar ratio; 25.7 and $23.2 \%$. The most diseases occurred in the first 25 days of lactation meaning $51.1 \% .16 .5 \%$ of this value occurred after the second calving. $13.4 \%$ of individuals got ill after the first calving. Ratio of diseases decreased between 26 and $50^{\text {th }}$ day of lactation meaning $6 \%$. Ratio of diseases was higher after the second and third calving. Between $51^{\text {th }}$ and $100^{\text {th }}$ days, ration of diseases started to increase meaning $15.5 \%$. It is visible from data, that in this phase the highest ratio of diseases occurred after the second calving with $7 \%$, then $3.2 \%$ got ill after first calving. Between $101^{\text {th }}$ and $150^{\text {th }}$ days of lactation, ratio of diseases decreased till $8.1 \%$. In this phase, the most diseases occurred after the second calving. Between $151^{\text {th }}$ and $200^{\text {th }}$ days of lactation disease ratio decreased again. However after day $200^{\text {th }}$ there was increment again. In the last phase of lactation $12.7 \%$ of all individuals got ill. In this phase the most frequent ratio of illnesses occurred after the first calving representing $4.2 \%$. As a conclusion, the most diseases occurred after the first three calving meaning $83.8 \%$. Considering phase of lactation more than half of the individuals got ill in the first 25 days firstly. After this decreasing tendency was typical considering firstly appeared diseases excluding $51-100^{\text {th }}$ days of lactation. New increment occurred after the $200^{\text {th }}$ day. There was significant difference in the distribution of investigated indicators after statistical probe was made $\left(\mathrm{Chi}^{2}=24.920, \mathrm{df}=20, \mathrm{p}=0.205\right)$.

\section{CONCLUSIONS}

According to BASCOM AND Young (1998) and CHIUMIA ET. AL (2013) preliminary culling reasons are reproduction disorders, mastitis, low productivity and lameness. In this research all appeared but with different order. Mastitis took the first place, then were other diseases, injuries. The third main reason was reproductive disorders. Low productivity and lameness ocurred in low percentage. Dairy cows can also be culled during lactation and 
mastitis can occurs at any phase of lactation (GRÖHN ET AL. 1998). SHOOK AND SCHUTZ (1994) found that is somatic cell count increases it is related to mastitis. Based on the results somatic cell count of culled cows was above 1 million in every cases. The rate of the SCC above 1 million cells $/ \mathrm{ml}$ in the milk is increased with lactation number. From this it can be concluded that the cullings were mainly caused by clinical mastitis. This is supported by HARASZTI's (1996) statement; he says if the somatic cell count is above 1 million we can speak of clinical mastitis. According to AlHUSSEIN AND DANG (2018) considered this value between 500000 - and $750000 \mathrm{cell} / \mathrm{ml}$. Mastitis also has a dangerous effect on health and production of the animal (MÜLLER- SAUERWEIN, 2010). Mastitis is the most common and costly disease of dairy cows (HALASA ET AL. 2007; HoGEVEEN ET AL. 2011). Mastitis often causes early culling (ANSARI-LARI ET AL. 2012). Research found that the rate of culling should be reduced, especially with regard to mastitis. Thus length of productive lifetime can be increased. As a result, the genetic potential of cows would be better expolited and production costs would be reduced.

Holstein Friesian has become the world's best dairy cow recently. In addition to outstanding milk production there are many animal health problems, because this species has particularly sensitive constitution. The most cullings are caused by different diseases. Based on the results and the literature it was found that if the anount of culling can be reduced, milk production will be more efficiently and profitably. To do this, it is important to prepare veterinary management and increase professional knowledge, furthermore ask expert advice. The most cullings occured due to mastitis. Strict adherence to a welldeveloped udder health program helps to prevent mastitis. Thus higher production of the herd will appear if the culling proportion decreases.

\section{REFERENCES}

ALHUSSEIN, M. N., DANG A. K. (2018): Milk somatic cells, factors influencing their release, future prospects and practical utility in dairy animals: An overview. Veterinary Word 11(5): 562-577.

ANSARI-LARI, M., MOHEBBI-FANI, M., ROWSHAN-GHASRODASHTI, A. (2012): Causes of culling in dairy cows and its relation to age at culling and interval from calving in Shiraz, Southern Iran. Veterinary Research Forum 3(4): 233-237. https://www.ncbi.nlm.nih.gov/pmc/articles/PMC4313041/

BASCOM, S. S., YOUNG, A. J. (1998): A summary of the reasons why farmers cull cows. Journal of Dairy Science 81(8): 2299-2305.

BEAUDEAU, F. (1995): Cow's health and farmer's attitude towards the culling decision in dairy herds. PhD. Thesis, Wageningen The Netherlands. Wageningen Agricultural University.

CHIUMiA, D., A. I., ROBERTS D CHAGUNDA M. G., MACRAE. J. (2013): Predisposing factors for involuntary culling in Holstein-Friesian dairy cows. Journal of Dairy Research 80(1): 45-50.

DERKS, M., VAN WERVEN, T., HOGEVEEN, H., KREMER, W. D. J. (2014): Associations between farmer participation in veterinary herd health management programs and farm performance. Journal of Dairy Science 97(3): 1336-1347.

GRÖHN, Y. T., EICKER, S. W., DUCROCQ, V., HERTL, J. A. (1998): Effects of diseases on the culling of Holstein dairy cows in New York State. Journal of Dairy Science 81(4): 966-978.

HALASA, T., HUIJPS, K., OSTERAS, O., HOGEVEEN, H. (2007): Economic effects of bovine mastitis and mastitis management: A review. Veterinary Quarterly 29(1): 18-31. 
HARASZTI, J. (1996): A tejtermelés és a tejhigiénia tőgyegészségügyi vonatkozásai. 151179 In: Tejgazdasági kézikönyv (Szerk. MERÉNY, I. - LENGYEL, Z.) Gazda Kistermelői Lap- és Könyvkiadó Kft., Budapest.

HOGEVEEN, H., HUIJPS, K., LAM, T. J.G.M. (2011): Economic aspects of mastitis: New developments. New Zealand Veterinary Journal 59(1): 16-23.

HOLLÓ, I., SZABÓ, F. (2011): Szarvasmarhatenyésztés elektronikus jegyzet. Kaposvári Egyetem-Pannon Egyetem.

KERSLAKE, J.I., AMER, P.R., O’NEILL, P.L., WONG, S.L., ROCHE, J.R., PHYN, C.V. C. (2018): Economic costs of recorded reasons for cow mortality and culling in a pasturebased dairy industry. Journal of Dairy Science 101(2): 1795-1803.

MÜLLER, U., SAUERWEIN, H. (2010): A comparison of somatic cell count between organic and conventional dairy cow herds in West Germany stressing dry period related changes. Livestock Science 125: 30-37.

SHOOK, G.E., SCHUTZ, M.M. (1994): Selection on somatic cell score to improve resistance to mastitis in the United States. Journal of Dairy Science 77(2) 648-658. 